\title{
Analysis of Affective Assessment Material in the Textbook Evaluation of Chemistry Learning Outcomes Based on SNPT and Curriculum KKNI
}

\author{
Helmi Fauziah Nasution \\ Postgraduate Students, Master of \\ Chemistry Education \\ State University of Medan \\ Medan North Sumatera, Indonesia \\ helmifauziahnst@gmail.com
}

\author{
Ajat Sudrajat \\ Department of Educational \\ Chemistry \\ State University of Medan \\ Medan North Sumatera, Indonesia
}

\author{
Iis Siti Jahro \\ Department of Educational \\ Chemistry \\ State University of Medan \\ Medan North Sumatera, Indonesia \\ jahrostiis@yahoo.com
}

\begin{abstract}
This study was aimed at describing: affective assessment material in the textbook evaluation of chemistry learning outcomes in the UNIMED chemical education study program according to the national standards of higher education and curriculum KKNI. This study was content analysis using the qualitative approach. The data analysis techniques used consisted of unitizing, sampling, recording, inferring, and narrating. The results of this study are as follows. (1) Most of the integrated indicators in the textbook are appropriate, but there are still material incompatibilities with the learning outcomes listed in the RPS(2) The content of affective assessmentunfulfilled most of the indicators, bu tit still needs to be equipped with the rubric to assist teachers in implementing the assessment. This assessment is to describe the ability of the students from the aspects of attitude, knowledge, and skills.
\end{abstract}

Keywords - Affective assessment, Curriculum KKNI, National standards of higher education. Introduction

\section{INTRODUCTION}

The demands of globalization have changed the pattern of increasingly fierce competition. The competition appears in several aspects, including the development of science and technology and the availability of jobs, it resulted in the formation of a national qualification framework (hereinafter referred to as KKNI) as an effort to stem the competition. Abstract The Indonesian National Qualification Framework (KKNI) is one of the national references to improve the quality and competitiveness of the Indonesian people in the human resource sector through the achievement of Indonesian human resource qualifications produced by the education system and the national job training system, as well as an equivalence assessment system for learning outcomes[1].

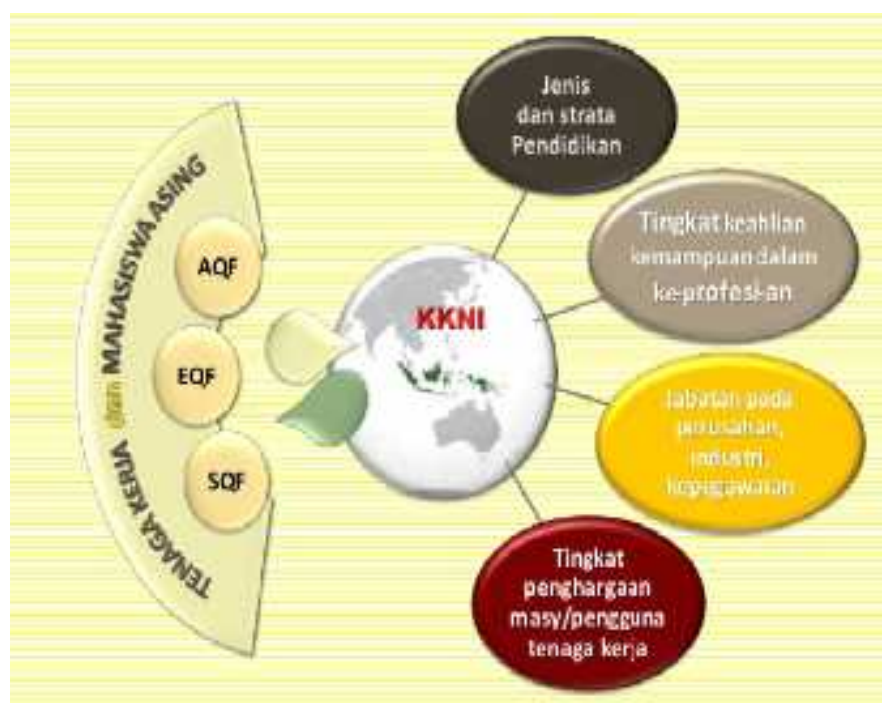

Fig I.The role of KKNI as equalizer of quality

KKNI is a frame of reference that is used as a measure in recognition of the education gap. KKNI is also referred to as a competency qualification skeleton framework that can juxtapose, equalize and integrate work education and training and work experience in the context of providing work competence recognition in accordance with the work structure in various sectors. [2]

According to Perpres No. 08 of 2012, KKNI is an embodiment of the quality and identity of the Indonesian Nation in relation to the national education and training system owned by Indonesia. So, it can be concluded that KKNI is a study program that requires the education system in Higher Education to clarify the profile of its graduates, so that it can be adjusted to suitability in the perspective of community needs analysis. This curriculum requires students to have abilities that meet criteria such as: 1) In the aspect of attitude; 2) Field work ability; 3) Knowledge; 4) Managerial and Responsibility.Assessment and student learning outcomes in curriculum concepts based on KKN includes: a) the 
principle of valuation b) assessment techniques and instruments c) assessment mechanisms and procedures d) conducting the assessment e) valuation reporting, and f) student graduation.

Learning tools that are important in order to succeed in learning are text books. Textbooks are an effective resource for self directed learning effective resource for presenting materials by the teachers, a source of ideas and activities, a references source for student, a syllabus that reflect predetermined learning objectives, and support for less experienced teachers who have yet to gain in confidence". [3].

Textbooks are an effective learning resource in the learning process for self-learning directly, an effective source for presenting content by the teacher, a source of ideas and activities, a source of reference for students.

According to the National Education Standards Agency eligibility criteriateaching materials are as follows: (1) component of content eligibility which includes: (a)material coverage (b) material accuracy (c) up-to-date (d) contains insightentrepreneurship (e) stimulates curiosity (f) contains life skills $(\mathrm{g})$ contains diversity insight $(\mathrm{h})$ contains contextual insight.(2) the language feasibility component which includes: (a) conformity withstudent development (b) communicative (c) dialogue and interactive (d) straightforward(e) coherence and the flow of thinking (f) conformity with language rules indonesia $(\mathrm{g})$ consistent use of terms and symbols / symbols. (3)The components of presentation eligibility include: (a) presentation techniques (b)supporting presentation material (c) presentation of learning. (4) componentgraphic which includes: (a) size / format, (b) design of the skin, (c) designcontents section, (d) paper quality.

Implementation of assessment in learning is a teacher activity to know the progress achieved by students. Based on the curriculum of 2013 [4] assessment conducted in learning includes three aspects, namely: cognitive /knowledge aspects, affective aspects/ attitude, and psychomotor/skills aspects. Most teachers do partial assessment, and generally only conduct on cognitive and psychomotor aspects only.

Affective assessment is important because it aims to obtain descriptive information about the behavior in terms of interest and motivation of students. The cognitive assessment is aimed to find out the intellectual progress of the students. The learning approach of inquiry laboratory used by teacher has important role to know the achieving level of students in cognitive aspect and affective aspect.The target of affective aspects by Krathwohl, et al in learning is to obtain descriptive information about the interests and motivation of students which include receiving, responding, appreciating, managing, and have the character. Automatically the affective aspect appears in every learning. Along with that, the research of suggests that the assessment of affective aspects shows a role to improve the learning. The target of cognitive aspects for students based on Bloom's revised taxonomyis knowing the intellectual progress consisting of a classification of knowledge and cognitive processes [5].

Affective assessment is generally concerned with describing how people feel, including such qualities as values, motivations, interests, attitudes, confidence, and anxieties, as they are directed to specific targets such as a course, instructor, text, or grade to be earned [4]. Although not often considered primary goals of college instruction, affective outcomes can complement traditional cognitive measures in assessing student progress [5]. Because of their influence on student behavior and motivation, affective outcomes provide important information about how students respond personally to a given academic experience [6] and suggest ways in which course instruction might be improved. [7] For example, [8] extensive interviews with college undergraduates have provided important insights about the kinds of teacher attributes that most positively impact students, what students believe is effective pedagogy, and how they respond to student diversity, and campus culture.

\section{METHOD}

This research in practice uses a qualitative approach with content analysis. Content analysis is a research technique for making inferences that can be reexamined and valid from data based on the context of its use. Research conducted on information documented in recordings, whether images, sounds, writing, or other commonly known as document research or content analysis [9]. This study attempts to understand the symbolic message in a document. The intended symbolic message is the content of the affective assessment. Documents analyzed were textbooks of evaluation and assessment of chemistry learning outcomes, affective assessment materials seen for compatibility with RPS.

Data collection techniques in this study are the careful reading and recording of textbook evaluations and assessments of chemistry learning outcomes. The main instrument used in this study is the human instrument that is the researcher himself, with the knowledge, accuracy, and criticality of the researcher searching and digging to find the data needed in accordance with the research problem.

The validity of the data in this study is based on validity and reliability. the validity used in this study is semantic validity, that is, the validity that explores the extent to which the categories of text analysis correspond to the meaning of these texts in the chosen context (Kripendorff, 2004: 323). Reliability used in this study is stability and reproducibility. Stability reliability is done by looking back at the available data sources repeatedly to get a consistent understanding of the data related to the aspects studied [9]. Reliability stability is referred to as intracoder reliability, because the data being compared is data from the same coder [10].

Data analysis techniques used in this study are content analysis schemes according to Kripendorff as follows: (1) unitizing (data collection) research objects that can be measured and assessed clearly, (2) sampling (determination of sample) ways to simplifying research by limiting observations that summarize all types of existing units so that units that have the same theme / character are collected, (3) recording is done recording and description of the book content, (4) reducing (reduction) is carried out by eliminating things that are not relevant to research, (5) inferring (conclusions) is done 
by analyzing the data further by searching for the meaning of the data units, (6) naratting (narration) containing information important information for research users so that they more understanding or can further make decisions based on the results of existing research.

TABLE I. INSTRUMENT

\begin{tabular}{|c|c|c|}
\hline No & Aspect & Indicator \\
\hline \multirow[t]{7}{*}{1} & \multirow[t]{7}{*}{ Feasibility of content } & Material Coverage \\
\hline & & Accuracy \\
\hline & & Finesse \\
\hline & & Growing Productive Character \\
\hline & & Stimulate curiosity \\
\hline & & Develop Life Skills \\
\hline & & $\begin{array}{l}\text { Developing Indonesian and } \\
\text { Constitutional Insights }\end{array}$ \\
\hline \multirow[t]{7}{*}{2} & \multirow[t]{7}{*}{ Feasibility of language } & $\begin{array}{l}\text { In accordance with the development of } \\
\text { students }\end{array}$ \\
\hline & & Communicative \\
\hline & & Dialogical and Interactive \\
\hline & & Straightforward \\
\hline & & Coherence and Mind Groove \\
\hline & & $\begin{array}{l}\text { Conformity with correct Indonesian } \\
\text { language rules }\end{array}$ \\
\hline & & Use of Terms, Symbols and Symbols \\
\hline \multirow[t]{3}{*}{3} & \multirow[t]{3}{*}{ Feasibility of presentation } & Presentation Techniques \\
\hline & & Supporting Presentation of Material \\
\hline & & Learning Presentation \\
\hline
\end{tabular}

\section{RESULT AND DISCUSSION}

The results in this study are data from careful reading and recording techniques of the content of affective assesments that show a lack of detailed explanation. The link with the applied curriculum KKNI, of course the book under study is still far from the curriculum concept. Especially in the provision of basic tasks typical of the curriculum KKNI. In the textbook, there were no specific topics or chapters that discussed learning assessments.

The contents of the book only generally explain the affective domain, as well as the types of attitude scales. Apart from the assessment of affective assessment material, the content contained in the evaluation book and the assessment of student chemistry learning outcomes, students still need a lot of improvement in accordance with the standards of higher education that refers to BSNP.

Further discussion regarding the importance of learning assessments in teaching and learning activities is expected to be presented not only in specific assessment books but in the learning evaluation book, even though in its scope it has the same principles and objectives and of course the books presented can also follow the development of the existing curriculum, so that the goal of improving the quality and quality of graduate outcomes, especially in higher education can be achieved

\section{CONCLUSION}

KKNI provides great benefits for lecturers and students, especially in providing skills and forming good character and character. Giving assignments to students has a positive impact going forward such as training discipline, making students more responsive and quick in making decisions and timely in completing each task.

The results of this study are as follows. (1) Most of the integrated indicators in the textbook are appropriate, but there are still material incompatibilities with the learning outcomes listed in the RPS(2) The content of affective assessmentunfulfilled most of the indicators, butit still needs to be equipped with the rubric to assist teachers in implementing the assessment. This assessment is to describe the ability of the students from the aspects of attitude, knowledge, and skills.

\section{REFERENCES}

[1] Jono, A. A.. Studi Implementasi Kurikulum Berbasis KKNI Pada Program Studi Pendidikan Bahasa Inggris Di LPTK Se-Kota Bengkulu. MANHAJ: Jurnal Penelitian dan Pengabdian Masyarakat, 2016.4(1).

[2] Solikhah, I.. KKNI dalam Kurikulum Berbasis Learning Outcomes. LINGUA: Journal ofLanguage, Literature and Teaching,12(1), 2015.p122.

[3] Roseni, E.. "Albanian Case: English Textbook Evaluation in High Schools as Part of the English Curriculum". Mediterranean Journal of SocialSciences, 6, 2014.p417-421

[4] Kemdikbud. Buku Guru Ilmu Pengetahuan Alam VIII, Kemdikbud, Jakarta.2017.

[5] Anderson, L.W., \& Bourke, S.F.. Assessing affective characteristics in the schools. 2000

[6] Simpson, R.D., Koballa, T.R., Oliver, J.S., \& Crawley, F.E.. Research on the affective dimension of science learning. In D.L. Gabel (Ed.), Handbook of research on science teaching andlearning. 1994. pp. 211234). New York: Macmillan Publishing Company.

[7] Popham, W.J.. Educational assessment's lurking lacuna. The measurement of affect.Education and Urban Society, 26, 1994.p404 416.M.

[8] Kitchen, E., Reeve, S., Bell, J. D., Sudweeks, R. R., \& Bradshaw, W. S.. The development and application of affective assessment in an upperlevel cell biology course. Journal of Research in Science Teaching, 200.744(8)

[9] Light, R.J.. Making the most of college. Cambridge, MA: Harvard University Press. 2001.

[10] Suharsimi, A..Manajemen Penelitian. Jakarta: Rineka Cipta. 2009.

[11] Eriyanto. Analisis Isi (Pengantar Metodologi untuk Penelitian Ilmu Komunikasi dan Ilmu-ilmu Sosial Lainnya). Jakarta: Kencana Prenada Media Group. 2011 